\title{
Are We Really Lacking the Effectiveness of Financial Resource Management in the Defence Sector?
}

\author{
Gábor BENCSIK'
}

\begin{abstract}
Recently, the increase of spending in the sector of defence has opened up larger and larger spaces for the development / modernisation potential of individual countries. However, in this "resource overflow", the effectiveness of the use of financial resources for defence is undermined. This study takes a look at the dangers of the ever-decreasing defence budget share (dangers well known in economics and well known in the field of defence sphere in the recent past) and the "free-rider effect" observed in different members states of the NATO (related to e.g. NATO Article 5) and reviews the effectiveness of financial resource management.
\end{abstract}

Keywords: defence spending, financial resource management, threats-security, cost-effectiveness, efficiency testing.

"If mathematics, including everything that rests on is, were somehow suddenly to be withdrawn from our world, human society would collapse in an instant." (Ian Nicholas Stewart) ${ }^{2}$

\section{Introduction}

The American economist and mathematician George Bernard Dantzig (1914-2005) is considered one of the pioneers, explorers and legendary figures of operations research. [1: 159-161] During the period of WWII, he spent a considerable time in the Pentagon (as the leader of Combat Analysis Branch of Statistical Control and later as the mathematical adviser of the Department of the U.S. Air Force [1]) and contributed to the explosive development of operations research as a complex branch of applied mathematics. The simplex method and algorithms to deal with transport problems have attracted the attention of contemporary scientists, especially Roland Neely McKean (1917-1993) and Charles J. Hitch (1910-1995). McKean and Hitch published their work in 1960 entitled The Economics of Defence in the Nuclear Age, in which they identify economically_as an economic problem of defencebasically three interrelated factors: the quantity and quality of national resources (1), the

\footnotetext{
$1 \quad$ Ph.D. student, National University of Public Service, Doctoral School of Military Engineering; Senior Financial Officer in the Ministry of Defence, Defence Economic Bureau; e-mail: bencsik.gabor@hm.gov.hu; ORCID: https://orcid.org/0000-0002-1394-6765

2 1945-, British mathematician. Source: [10].
} 
share of national resources dedicated to defence (2) and the effectiveness of the use of these dedicated resources (3). [2: v]

The extent of each nation's resources (1) used for defence purposes (2) is highly dependent on social support within the nation and on the political will. In addition to the scarcity of resources available in the complex system, we could observe a more pronounced downward trend in defence spending in the past (over several decades), which was steadily plummeting in recent years, but has taken a sluggishly rising path. [3]

Further narrowing the statistics we can observe the negative impact of the 2008 global economic and financial crisis on GDP-related defence spending world-wide, both within NATO and in many countries besides NATO [3] — despite the fact that in 2006, NATO member states accepted to spend $2 \%$ of their gross domestic product (GDP) on defence and armed forces to cope with the forthcoming challenges of the time. Relying on the collective defence established by Article 5 of the NATO Statute, [4] only a few member states are merely "beneficiaries" of the system, and this current situation is described in classical economics as an economic problem called "free-rider effect”. (cf. [5: 7])

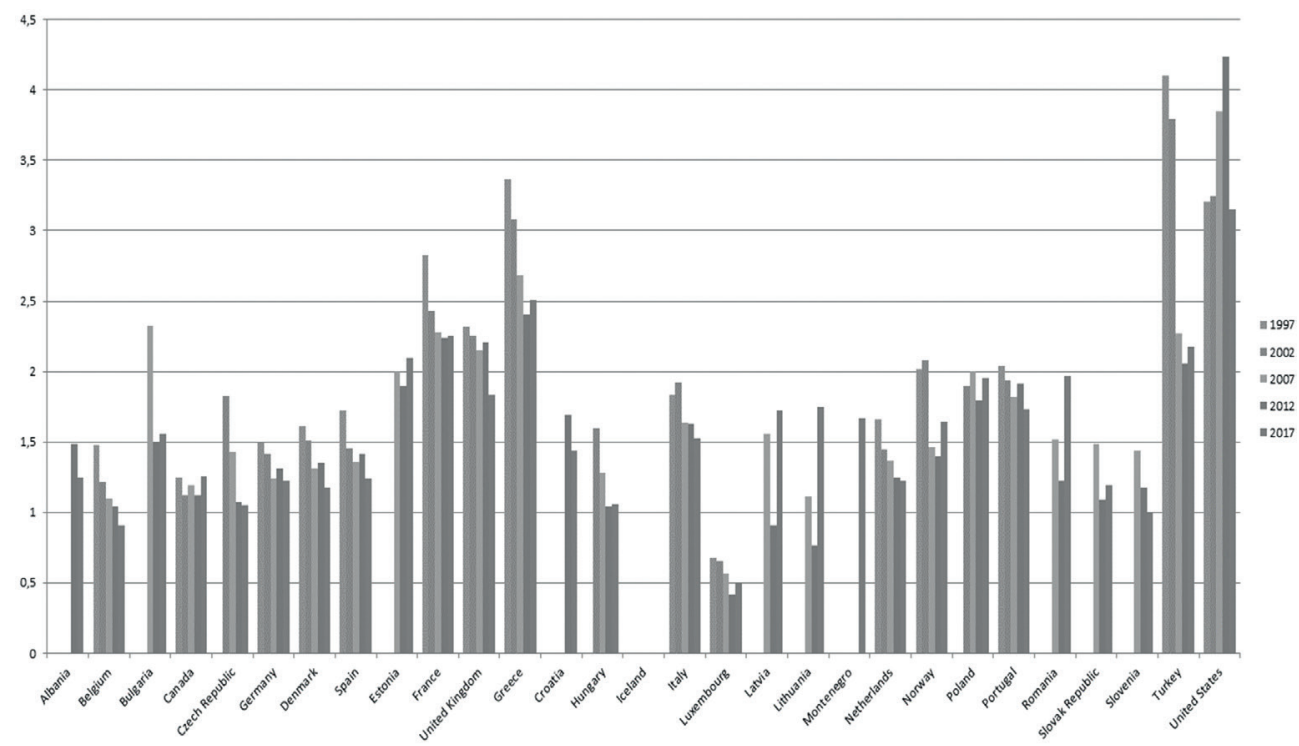

Figure 1. NATO member states' GDP-related defence expenditure over the last two decades. (Edited by the author based on [3].)

Keith Hartley also attaches considerable and particularly worrying consequences to the declining defence budget. Hartley noted in his writing of December 2016, The Economics of European Defence: "Falling or constant defence budgets in real terms and continued cost escalation mean difficult defence choices cannot be avoided: something has to go. Some nations have already confronted such choices and have abandoned a major capability.” [11: 2]

These processes, the significantly deteriorated security situation and the decreasing GDP-related defence expenditures in recent times have highlighted the need to re-monitor and further investigate a previous problem, namely how we can provide the best possible "end product” (solution) to the "customer" from a "unit of money (UoM)". 
G. BENCSIK: Are We Really Lacking the Effectiveness of Financial Resource Management...

\section{The Still Unresolved Issue of Optimal Financial Resource Management}

"Defence and security are controversial public goods. [...] Of course, the 'force-orientation' of the defence economy also depends on how strong a country's army is, how much it consumes, and how much it contributes to the GDP, the role it plays in implementing the country's foreign policy, and maintaining the country's internal security."

Zoltán Szenes ${ }^{3}$

As we read in the introduction, Hitch and McKean's 1960 publication [2] paid particular attention to the efficient use of resources dedicated to defence, which was identified as a key issue in defence management.

The limitations of defence resources (in the general sense, including material resources and services) can be traced back to the extent of the availability of financial resources. That is why the continuous, up-to-date examination of the optimal resource management of the financial resources devoted to the maintenance of security as a public good is particularly important. In Hungarian context, a study was published in 2003 by the Center for Security Policy and Defence Research (in Hungarian: Biztonságpolitikai és Honvédelmi Kutatások Központja Alapítvány - BHKK Foundation) entitled Designing the efficient use of resources in the defence sphere, with particular regard to financial resources. [7] The study - as its title suggests - attaches particular importance to the examination of the use of financial resources, especially those available to the defence sector. However, if we observe more thoroughly, the study, which processes historical data and procedures, can be dated several years back, when the budget share, which had been reduced in relation to the GDP until 1999, was for a short term on a rising trend. ${ }^{4}$ Apart from all these, the period defined by defence spending on the rising trend is characterised by the following statement: "In the course of economic planning, feasibility studies as well as cost and effectiveness analyses are not prepared with the required level of detail." ${ }^{5}$ [7: 50]

\section{The Background of Cost- and Effectiveness Analysis (Threat and Security)}

"There is no clear vision about what kind of defence economics would serve the most the nation's interest in the circumstances of market economy, in the changing security situation."

Zoltán Szenes ${ }^{6}$

The performance of economy is crucial for the defence power of a country. In a well-operating economy, it is possible to raise other important capabilities, such as military capabilities, to the competent (expected) level. However, with increasing defence spending, there is increasing pressure on responsible and efficient financial resource management as well.

3 Former Chief of the General Staff of the Armed Forces of the Republic of Hungary (2003-2005). Source: [6: 10, 12]. Translated by the author of this article.

4 Note: Subsequently, following our accession to the European Union in 2004, a decline in the share of GDP was again observed. Cf.: [5: 7].

5 Translated by the author of this article.

6 Source: [6: 6]. Translated by the author of this article. 
Numerous scholarly works offer in-depth knowledge of cost and effectiveness analysis. The 2003 BHKK study refers to the cost-effectiveness of defence spending as follows: "In planning and decision-making work, the cost-effectiveness approach (more for less principle) results in improved organisational performance.” ${ }^{7}$ [7: 5]

The management of this era (both at the level of military tactics management and military strategy management) was primarily determined by the cost-effectiveness approach ("more for less” principle). We should not be surprised by this: as mentioned before, the Hungarian army has undergone significant decommissioning in the few decades preceding that period.

At the moment, however, we are in the midst of another military reform, ${ }^{8}$ which intends nothing more than a correspondence with the requirements mentioned in many other previous articles, taking into account necessity and timeliness. We could see that the rise in defence expenditures to the proportion of $2 \%$ of the GDP was formulated as an international and national priority, the target date of which was set by the Hungarian government in 2024. [8: point 1] The planned increase in financial resources can be measured in hundreds of billions of HUF, because of which the opportunity has now come for the real development of national defence. However, the objective of the actual development concerns not only the absolute use of the available resources, but also the importance of efficient financial resource management and, if necessary, the reconsideration of management procedures/ methods.

The reconsideration of military management procedures/methods is not only a military matter but also a national requirement. Optimal use of the defence budget can be compared to the perfect market in the economy, which, as is known, only exists in theory. In addition to the homogeneity of goods, perfect information, rational decisions, temporal and spatial identities, and the absence of immediate reactions, we have to reckon with various national security factors that complicate even more the complex mathematical models. We often mention the importance and role of effective financial resource management in the $21^{\text {th }}$ century as a "trendy and fashionable way", but how does this work in the practice? How effective is the financial resource management of the defence sector (both within and outside Hungary)? How do we calculate/measure the efficiency of the financial resource management?

In order to answer the questions raised, let's start with the basics, that is, first of all, we need to examine why we need protection. What is protection and how much is it needed?

According to the Explanatory Dictionary of the Hungarian Language [12] issued in 1959-1962 by the Academic Press, the defence is an "active preservation, defence, protection, and protection of the physical integrity, life and integrity of someone”, and "the

\footnotetext{
Translated by the author of this article.

8 Note: a military reform provides an excellent opportunity to rethink and develop the functionality and methods of the army. The mentioned study by the BHKK Foundation highlights: "In the context of military development, all structural, management and operational transformations that ensure the most efficient management and use of forces and assets must be implemented. However, the first pace of the transformation is not in the exchange of applied military equipment and weapon systems, but in the re-thinking of applied organisational and management procedures.” [7: 88] The referenced military reform is the Zrínyi 2026 Defence and Military Development Program, which is referred to by various organs as the largest defence and military development program of the past 26 years.
} 
defence activities and operation of armed forces, protecting organisations against (military) attack". 9

Based on all these, defence is generally expressed as a response to a particular threat or its prevention. With the application of protection, we have no other purpose than to reduce the level of threat, to create security, or to increase the existing security level. The relationship between threat and security is illustrated in Figure 2 below:

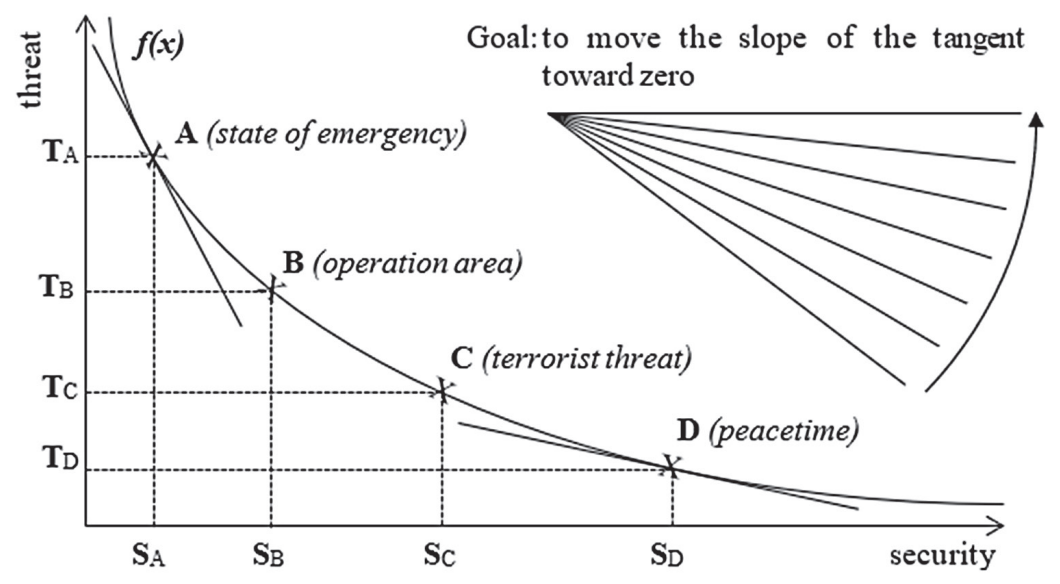

Figure 2. The relationship between threat and security [f(x)].

[Edited by the author.]

Figure 2 shows four alternative options that not only illustrate the relationship between security and threat, but will help us to understand how the efficiency of financial resource management can be interpreted in different cases. The four alternatives shown are:

- A: during a special legal period, in case of the state of emergency;

- B: in a high-risk operation area;

- C: during a special legal period in case of a terrorist threat;

- D: in peacetime.

In the four alternative options outlined, we can discover a number of common points, such as all four points are on the common curve between threat and security, and in all four cases, the threat level is reduced, leading to an increase in the level of security. However, this objective can be achieved by different methods and procedures at different points. We only need to think about how much IT security development reduces the threat at " $\mathrm{A}$ " or how the same development contributes to the increase of the level of security at point " $D$ ". It is clear and obvious that this kind of development in peacetime ("D") can contribute much more to an increase of the level of security, since it can provide adequate security against a possible cyberattack. However, the same development is not likely to show the same level of security increase in an emergency situation ("A") where the rules of direct combat contact dominate. Here, we can immediately be attentive to the "time" factor, which

9 Translated by the author of this article. 
is why it is essential that we have the time to respond to the (response) challenges we face. On the basis of these, it can be seen that efficient management with the available resources is rather complex and in different cases it is at a different level. We can consider as our primary objective to create a function describing curve, after which the approximation to optimal financial resource management can be achieved by applying differential geometry.

Taking into account this example (defence IT development), and returning to the correlation and relationship system outlined in Figure 2, it can be concluded that the management of defence budget resources can be considered effective if it can reduce the threat level, thereby increasing the level of security. The higher the rate of this change, the better we approach the level of optimal (non-existent) financial resource management. In general terms: in the field of financial resource management, the efficiency of the management process can be measured by the-indirect or direct-result of measures aiming at the reduction of the level of measurable threat, using the "unit of money (UoM)" for measurement.

Concerning the notion "efficiency of financial resource management of defence resources”, the efficiency of this management process is the aggregate rate of the efficiency factor of each sub-process. On the basis of these, the implementation of the sub-processes of financial managing should seek to maximise the contribution of management to a positive shift in the threat-security curve (to an increase of the safety level). However, it can be noticed that the aggregate value/level must represent a continuously calculated value/level (see Figure 3). Based on these, constructive sub-processes with added value in the field of efficient management can be considered as if the effect of their threat-reducing/safetyincreasing value on the threat-safety curve led to a positive shift. Determining this property is independent of the actual aggregate efficiency value, which means that a subprocess can be considered effective even if it involves an aggregate efficiency level decrease but also a safety level increase, and can be considered ineffective if its aggregate efficiency level is increased, but has a safety-reducing effect (see Figure 2).

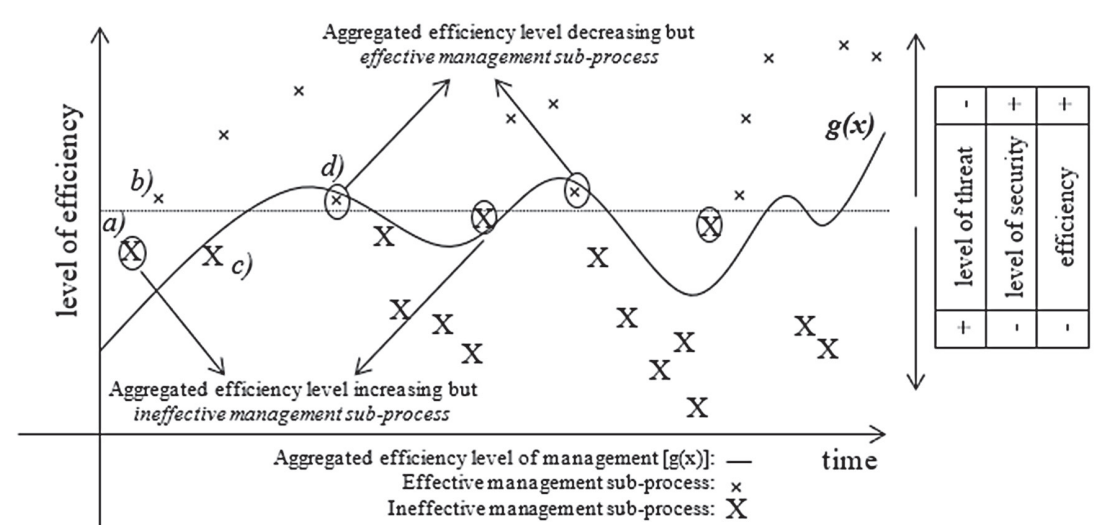

Figure 3. The illustration of the role of decisions affecting the financial resource management processes in supporting/enhancing their effectiveness.

[Edited by the author.] 
The decision points shown in Figure 3 illustrate the role of each decision in the effects on the threat and security level, taking into account their status in relation to the aggregated efficiency level. The figure clearly shows that although the large $\mathrm{X}$ indicated in a) reduces the level of security (and simultaneously increases the threat level), its contribution to the aggregate efficiency level is constructive. If we consider our earlier statement that "the implementation of the sub-processes of financial managing should seek to maximise the contribution of management to a positive shift in the threat-security curve,” it can be stated that although the value indicated in $a$ ) has a positive effect on the aggregate efficiency level, at the same time, it is not constructive concerning the safety level, and does not increase efficiency. Accordingly, the decision value in a) is not considered effective. This statement is also supported by the value in $c$ ), the effect of which is to increase the level of threat to be equal to the value in $a$ ), except that the effect of this value on the aggregate efficiency level is also negative.

However, the values in $b$ ) and $d$ ) are already the result of an efficient management process based on their positive impact on the level of safety. The difference between the two points on the same level can be seen in their effect on the aggregate efficiency level. It can be seen that while the level of the effective management decision in $b$ ) has a positive effect on the aggregate value, the same property can no longer be attributed to the value indicated in $d$ ). Regardless of all these, both points have the same efficiency factor as they are capable of increasing the level of security with the same degree.

In the periods shown in Figure 2, all of the management decision alternatives can be found at almost all levels of financial resource management. Taking into account the correlations of Figure 3, we can conclude that the effectiveness of individual financial resource management processes are determined by their impact on threat and safety levels, and this result is independent of the aggregate value of the efficiency level.

\section{The Impact of the "High Level” Protection Budget and the Importance of the Decision Duration}

As mentioned earlier, in different periods of time (cf. Figure 2), there are different time intervals for managers to make decisions. As is often the case with leadership theory education, there is no wrong decision, all decisions are adequate at the given time, and our idea of judging the decision can be changed as time goes by. Therefore, the importance of the time-factor in explaining the problem is quite pronounced.

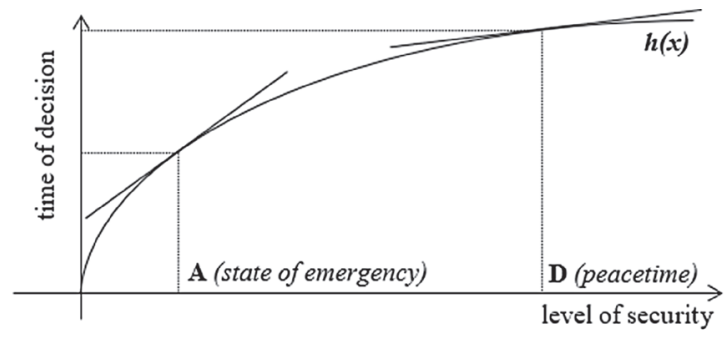

Figure 4. The relationship between security level and time of decision making [h(x)].

[Edited by the author.] 
From the context shown in Figure 4, we can see that the higher the security level of a country, the more time it takes for leaders to make defence decisions (cf. "peacetime" and "state of emergency"). Here, it is apparent that our aim is to reduce the first derivative value of the function $\mathrm{h}(\mathrm{x})$, which represents the relationship, to the level 0 , by which convergence can be achieved towards the maximum-security level and the corresponding high-value time factor.

On the other hand, however, it can be stated that the lower the amount of (financial) resources available to military leaders, the more they are forced to make their decisions in favour of a cost-effectiveness approach ("more for less"). However, low (financial) resources have low effects. That is why the issue of effective financial resource management is placed in the background and the role of the above-mentioned "more for less" approach is maximised. In this case, in the short term, one of the goals is "as much as possible to get more". The problem arises only if we apply our existing methods based on this approach and, in the event of a possible increase in resources, we stick to the "well-known" procedures, ignoring the characteristics of the various factors of the descriptive function(s) that are currently being described, and their values. In this case, the impact of the increase in defence spending is in many cases less than expected:

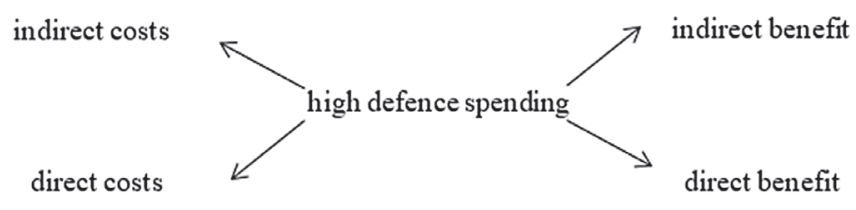

Figure 5. Illustration of the effects of defence spending.

(Edited by the author based on [2: vi-vii].)

The level of protection expenditure shown in Figure 5 may have a number of impacts also beyond the direct defence sphere. Accordingly, the efficient use of defence resources-both the direct and the indirect uses - affect the entire national economy (as well as its actors). Considering these relationships, it can also be concluded that the level of defence spending is nothing other than the amount of money spent by a given player (economy) on security. We can define how this "purchase" is carried out, how efficient it is, by the methods used by the actors involved (with defence spending), and by the quantifiable results of the methods and procedures applied.

From the methods described above the primary and most important is the specification of the descriptor variable, and the exact determination of its components. After the definition of the functions of the components - if it is a hypothetical function as outlinedour primary goal is to move the slope of the tangent to a given point of the functions toward 0 . This displacement can be carried out by differential calculus, if necessary, using a partial derivation method. However, we must be careful that while in some decisions our primary goal is the reduction of the slope of the affected function (Figure 4), in other cases the goal is to increase this value (Figure 2). If the decision to be taken supports the shift to these directions, then we can talk about an efficient management sub-process. In all other cases, the result falls below the decision criterion level, so it is advisable to reject them (see the large X’s in Figure 3). 


\section{The Problem of Resource Limitation and the Defence Economics Conundrum}

Our recent developments in military technology, demanded by the dynamics of the era, the information warfare in our world, the modern telecommunication systems and tools have greatly transformed our vision of todays' warfare. However, one thing is permanent: the security of a nation is mainly determined by the nature and rational amount of equipment used by its military - among other technical and economic factors-and thus the extent of the national resources dedicated to the realisation of these developments and the utility of developments.

Of course, the development of a nation is determined by its core capacities, in particular the proportion of national resources (material, technical, manpower, etc.) made available for the determined purpose. At the same time, we need to deal with the determination of the proportion of these resources with caution, leaving sufficient margin for the development of security. However, the size of the resources dedicated to defence management has been strongly influenced. These influences depend not only on the performance of a particular nation, but on the political will representing the nation's interest and will, the international pressure and other threats present.

The amount of resources devoted to defence management is primarily represented by the total of approved budget appropriations for ministries involved in defence. However, the margin for budgetary appropriations is sufficiently flexible to determine the proportion of personnel, operational and development expenditure, which plays a key role in budgetary planning. Analysing these ratios, we can rightly assume that we have a good view of a country's defence economy, because if the share of personal costs is high compared to the other two, then it can be rightly argued that the defence structure of that country is based on obsolete, less automated military technology. At the same time, Hitch and McKean, in their work Economics of Defense in the Nuclear Age published in 1960, highlight the impact of the acquisition of military equipment on budget planning. They point out: “The prices of goods to be bought in the future are uncertain. One course of action may itself drive up the price of particular weapons or materials, and it is not possible to predict these effects with complete accuracy. The characteristics and cost of some exceptional items may literally be fixed, or nearly fixed, even if we are looking several years ahead. Nonetheless, imperfect as it is, the money cost of a future program usually shows the sacrifice that would be required of the Department better than other measures.” [2: 26]

At the same time, Hartley, outlining the shortcomings of the European defence policy, sets out general economic principles to promote more efficient use of resources for defence management. [11: 2-4] In his writing he highlights:

- the benefits of pure competition against monopoly, oligopoly and monopolistic competition, reflects its high value adding role of innovation, ensuring a market price;

- the role and importance of specialisation based on the comparative advantages of each country;

- the role of economies of scale, international projects and R\&D;

- the importance of the role of club goods (public goods typical of the defence industry);

- the role of substitute products;

- and last but not least, the priority of the effect of output of the defence, which is described as below: „Major reviews of defence usually focus on inputs rather than defence outputs. 
Inputs in the form of the numbers of military personnel and numbers of combat aircraft, tanks and warships dominate debates. This is the wrong method - the focus should be on the contribution of inputs to defence output in the form of peace, protection and national security. Admittedly, there is an absence of money values for defence output, but the output focus is economically correct. Moreover, there should be an additional focus on the effects of small changes in inputs on defence outputs. For example, what are the effects of a smaller or larger air force on defence output; similarly, for a smaller or larger army and navy?” [11: 4]

\section{Conclusion}

In recent times, with the increase of economic performance that broke the downward trend following the global crisis in 2008, we can see an increasing level of aggregate defence spending. The United States is ranked first among the countries with the highest defence spending in the world (2016: \$ 611 billion [1.7\% growth compared to 2015]) excluding China, Russia, and India who can count 5.4\%-8.5\% rise in defence spending by looking at data from 2015 to 2016. [3]

However, it can be observed that increasing military spending from 2014 is not necessarily consistent with the development needs of the defence industry required by nations/economies. This is explained by the fact that in individual countries the "threat factors" present are observed as a "military problem” and they often ignore the issue of an efficient resource allocation of defence resources that are closely related to it. Alas, this is by the fact that in the recent past an exact mathematical model was not revealed and the correction of the previously created models was not realised.

The poetic question raised in the title does not require any particular explanation. It can be seen that in the current security environment, the companies-with their over-appetite for profit-do not address the issue of national defence as a primary issue. Summarising the above, it is clear that all factors affecting (civilian and military) management must be a matter of defence (and must be planned at all levels and for each portfolio) as a priority issue.

We can say that developing the domestic defence industry is of key importance. The Hungarian Defence Forces Modernisation Institute established on $1^{\text {st }}$ January, 2019 provides an excellent opportunity for Hungary, as well as the Zrínyi 2026 Defence and Military Development Program launched in the recent period, which in terms of volume is simply a huge set of opportunities. However, exploiting these opportunities should be based on scientific principles, taking into account the limitations of resources, increasing the efficiency of defence financial resource management, while maximising the usefulness for society. Following the creation of the necessary theoretical foundations, a possible microsimulation model-including mathematical methods, especially operations research results and graph theory — could be used to map the aggregate effects of the planned measures, which would provide an opportunity to carry out a complex, multi-dimensional analysis, and thus an impact study, making up for the lack of necessary feasibility studies and cost-effectiveness analyses, the lack of which affected economic planning. All these "needs" are confirmed by the words of the president of the Hungarian Academy of Sciences (in Hungarian Magyar 
G. BENCSIK: Are We Really Lacking the Effectiveness of Financial Resource Management...

Tudományos Akadémia, MTA), László Lovász, who has told in May 2018, at the $189^{\text {th }}$ General Assembly of this institute, the following: "Scientific questions of public interest should be answered by a scientific method based on internationally accepted standards.” [9]

\section{References}

[1] PRÉKOPA A.: George Dantzig (1914-2005). Alkalmazott Matematikai Lapok (Az MTA Matematika Tudományok Osztályának Közleményei), 241 (2007), 159-161.

[2] MCKEAN, R. N. - HITCH, C. J.: The Economics of Defence in the Nuclear Age. Santa Monica, The RAND Corporation, 1960.

[3] Military expenditure (\% of GDP). Washington, D.C., The World Bank - Data, 2019. https:// data.worldbank.org/indicator/MS.MIL.XPND.GD.ZS (Downloaded: 26.02.2019)

[4] The North Atlantic Treaty. Washington, D.C., 1949. NATO. www.nato.int/cps/en/natohq/ official_texts_17120.htm?selectedLocale=hu (Downloaded: 27.02.2019)

[5] BALLA T. - BOROS I. - BENCSIK G.: A biztonság iránti kereslet, avagy a védelmi kiadások másik oldala. Költségvetés, Pénzügy, Számvitel (a HM Védelemgazdasági Hivatal tudományos-szakmai kiadványa), 2 (2017), 4-15.

[6] SZENES Z.: A védelemgazdaság helyzete Magyarországon. Katonai Logisztika, 2 (2015), 5-52. http://epa.oszk.hu/02700/02735/00080/pdf/epa02735_katonai_ logisztika_2015_2_005-052.pdf (Downloaded: 27.02.2019)

[7] Az erőforrások hatékony felhasználásának tervezése a védelmi szférában, különös tekintettel a pénzbeni erőforrásokra. [Study] Budapest, BHKK Alapítvány, 2003. www.mtaita.hu/hu/ Publikaciok/BHKK_OTKA.pdf (Downloaded: 27.02.2019)

[8] A honvédelmi kiadások és a hosszú távú tervezés feltételeinek megteremtését szolgáló költségvetési források biztosításáról szóló 1273/2016. (VI. 7.) Korm. határozat.

[9] Az Akadémia a tudományos módszer mellett állt ki - Lovász László elnöki beszámolója. https://mta.hu/kozgyules2018/az-akademia-a-tudomanyos-modszer-mellett-all-ki-lovaszlaszlo-elnoki-beszamoloja-108702 (Downloaded: 28.02.2019)

[10] STUART, I: Nature' numbers: The unreal reality of mathematics. New York, Basic Books, 1995.

[11] HARTLEY, K: The Economics of European Defence. Paris, Armament Industry European Research Group, 2016. www.iris-france.org/wp-content/uploads/2016/12/ARESGroupEconomics_of_European-Defence-d\%C3\%A9c2016.pdf (Downloaded: 28.02.2019)

[12] A magyar nyelv értelmező szótára. Budapest, Akadémiai, 1959-1962. 